\author{
Wojciech STILLER, PhD, Professor \\ Department of Business and Economics, Berlin School of Economics and Law \\ e-mail: wojciech.stiller@hwr-berlin.de \\ ORCID: 0000-0003-4578-8869
}

DOI: $10.15290 /$ oes.2020.03.101.02

\title{
THE VAT COMPLEXITY, A COMPARATIVE ANALYSIS FOR GERMANY AND POLAND ${ }^{1}$
}

\begin{abstract}
Summary
Purpose - This article aims to examine the complexity of the value added tax (VAT) in Germany and Poland.

Research method - This paper uses a quantitative analysis of the VAT Act and a selected amendment to this Act in Germany and Poland. I consider the German and Polish language versions of the VAT Directive and the Vouchers Directive as a benchmark for comparing VAT complexity. A comparison of a number of law amendments and compliance costs in both countries enhances the analysis.

Results - The VAT complexity in Poland significantly exceeds the complexity of the German VAT system. This is true for all analysed aspects. In Poland, the compliance costs of VAT are significantly higher than in Germany. The Polish VAT law is amended more frequently and is much more comprehensive than its German counterpart. This can be only partially justified by special regulations to combat tax fraud. The high VAT complexity in Poland is also due to the complicated language and structure of the law. Although the German translation of the Vouchers Directive includes more words than the Polish version, the Polish legislator needs about twice as many words as their German counterpart for its implementation.

Originality / value - Tax law is often criticised for its complexity. This study is the first to use the VAT Directive for a comparative study of the VAT complexity and reveals that the Polish legislator uses considerably more text for similar content than their German counterpart.
\end{abstract}

Keywords: compliance costs, complexity, Germany, Poland, language analysis, legislation, tax, VAT

JEL Classification: K34, Z13

\section{Introduction}

Tax law is criticised for its complexity, resulting in claims for tax simplification. The importance of this issue is indicated by initiatives to simplify the tax system in countries such as Australia, New Zealand and the UK [see: James et al., 2015]. In the latter, the Office of Tax Simplification was established about a decade ago to provide the government with independent advice on tax simplification [see: OTS,

1 Article received on 9 March 2020, accepted on 20 May 2020. 
2020]. The complexity of tax law has long been the subject of numerous and varied studies that examine, among other things, the causes and consequences of tax complexity.

The tax complexity is not clearly defined. The Cambridge Dictionary defines complexity as the state of having many parts and being difficult to understand or find an answer to. If we apply this definition to taxes, tax complexity consists in the multi-dimensional nature of the tax system, which makes it difficult to determine the tax treatment of a given case. Tax complexity can have many causes related to the principles and functions of taxation. Legislators see taxes not only as a source of state revenue (fiscal function), but also as an instrument of social policy (redistribution function) and an instrument of economic policy (stimulating function). As a result, the basic structure of the tax system is complicated by numerous exceptions, such as special tax rates, tax exemptions and special deductions that are associated with tax complexity [Warskett et al., 1998].

Interestingly, however, on one hand the complexity of tax law is criticised by the same people who (unconsciously) demand its continuation. The chairman of the German Free Democratic Party (FDP), for example, is committed to the simplification of tax law and at the same time argues in favour of special tax regulations to stimulate the economy [see: Schäfers, 2010; Lindner, 2020]. I observe this pattern of behaviour very often. My students and friends criticize the complex German tax system. However, when I propose a solution in the form of abolishing a special regulation that I know they benefit from, they become sceptical about the simplification of tax law.

The fact that tax complexity is difficult to eliminate or that its reduction is not necessarily a desirable purpose is also due to the complexity of the economic environment. Tax law is mainly decided unilaterally, but is also intended to cover international transactions. The tax legislation should avoid double taxation and prevent undesirable tax planning approaches.

The above arguments in favour of tax complexity must be considered taking into account negative consequences mainly in terms of compliance costs (on complexity as the driver for compliance costs, see Eichfelder, Vaillancourt [2014]).

The difficulty in defining tax complexity results in the difficulty in quantifying it. The relationship between tax complexity and compliance costs suggests the use of these costs as a measure of complexity [Slemrod, 1984]. However, determining compliance costs is not a straightforward task, hence many methods have been developed to calculate these costs [Pedersen et al., 2013]. Apart from the cost-based measurement of tax complexity, methods are used that focus on the readability or the size of tax regulations, forms or instructions. Slemrod [2005], for example, uses the number of lines in a tax form as well as the number of pages in the instruction booklet as a proxy for the complexity of the US income tax. In the recent literature, various components such as the perception of practitioners and compliance costs [Hoppe et al., 2019] or costs of complexity (compliance and administrative costs) and readability [OTS complexity..., 2015] are considered together to measure tax complexity. 
This paper uses the proxies for compliance costs, the number of legal changes and the volume of tax laws for comparing the VAT complexity between Germany and Poland and takes advantage of the fact that the VAT law in both countries has the same foundation in the form of the VAT Directive.

The remainder of this article is structured as follows. Section 2 presents the development of the VAT law in Germany, Poland and in the EU. Section 3 deals with the analysis of the VAT complexity in both countries using compliance cost indicators and a comparison of the legal texts. Section 4 constitutes a conclusion.

\section{VAT legislation in the EU, Germany and Poland}

In order to introduce the common market, Article 99 of the Treaty establishing the European Economic Community of 1957 stipulated standardisation of the Member States rules on indirect taxation.

About a decade later, the Council of the European Economic Community enacted the First Directive that forced the Member States to replace their system of turnover taxes with the common VAT system [Council of the European ..., 1967a]. The 6-article, two-page Directive designed the VAT as a general consumption tax, proportional to the price of goods and services. Taxation at all stages of the value added chain was accompanied by the right to deduct the input tax. In addition, the Second Directive provided more detailed information on the structure and application of the common VAT system with 21 articles and 2 annexes on 8 pages [Council of the European ..., 1967b].

A further decade later, the Sixth Council Directive, with 38 articles and 6 annexes on 40 pages, repealed the Second Directive and substantially specified the common VAT system [Council of the European ..., 1977]. The purpose of this Directive was to introduce a uniform tax base in the Member States.

Due to substantial amendments and for reasons of clarity, the Council of the European Union recast the Sixth Directive in 2006 [Council of the European Union, 2006]. Without taking into account the overview on linking the old and new versions, the recast (VAT Directive) contains 414 articles and 11 annexes on 80 pages, which reflects the progressive development of the VAT legislation in the EU.

In addition to the VAT Directive, the European VAT system is based on further directives (e.g. Directive 2008/9/EC on the VAT refund), as well as on the VAT Implementing Regulations, which are to ensure a uniform application of the VAT Directive. In contrast to the Directives, the Implementing Regulations are directly applicable, i.e. without implementation in national law [Existing EU legal..., 2020].

The German turnover tax system has its roots in the First World War, for the financing of which the German Reich introduced the goods turnover stamp in 1916. The subsequent Turnover Tax Act (of 26.7.1918) designed the tax as an all-stage tax on supplies and services. This tax had a cumulative effect, since neither the input turnover nor the input tax was deductible (gross turnover tax). As a result of the development of the European Community law described above, the VAT system has 
been in force in Germany since 1 January 1968 (German VAT Act 1967), which was reformed according to the Sixth Directive by the German VAT Act 1980 [Klenk, 2019]. The applicable VAT law in Germany is based on the VAT Act and the VAT Implementing Regulation (both in the recast version of 21 February 2005).

In Poland of the interwar period, various turnover taxes were applicable. The generally valid and modern VAT came into force at the beginning of 1939, but its proper application was not possible for historical reasons. After the end of the Polish People's Republic, the Act on the Tax on Goods and Services and on Excise Tax was adopted in 1993. As a logical consequence of Poland's accession to the EU in 2004, the VAT law was reformed with the currently applicable VAT Act of 11.03.2004 [Krótke historia VAT..., 2019]. Besides the VAT Act, Polish VAT law also includes the regulations of the Minister of Finance.

The recast of the Sixth Directive in force since 2007 and its amendments constitute a basis for the VAT laws and their development in Germany and Poland. Therefore, a comparison of the legislation in terms of the number of amending laws in the years between 2007 and 2019 is appropriate to identify the first indications of tax complexity in both countries (chart 1).

\section{Number of laws amending the Polish and German VAT Act and the EU VAT Directive}

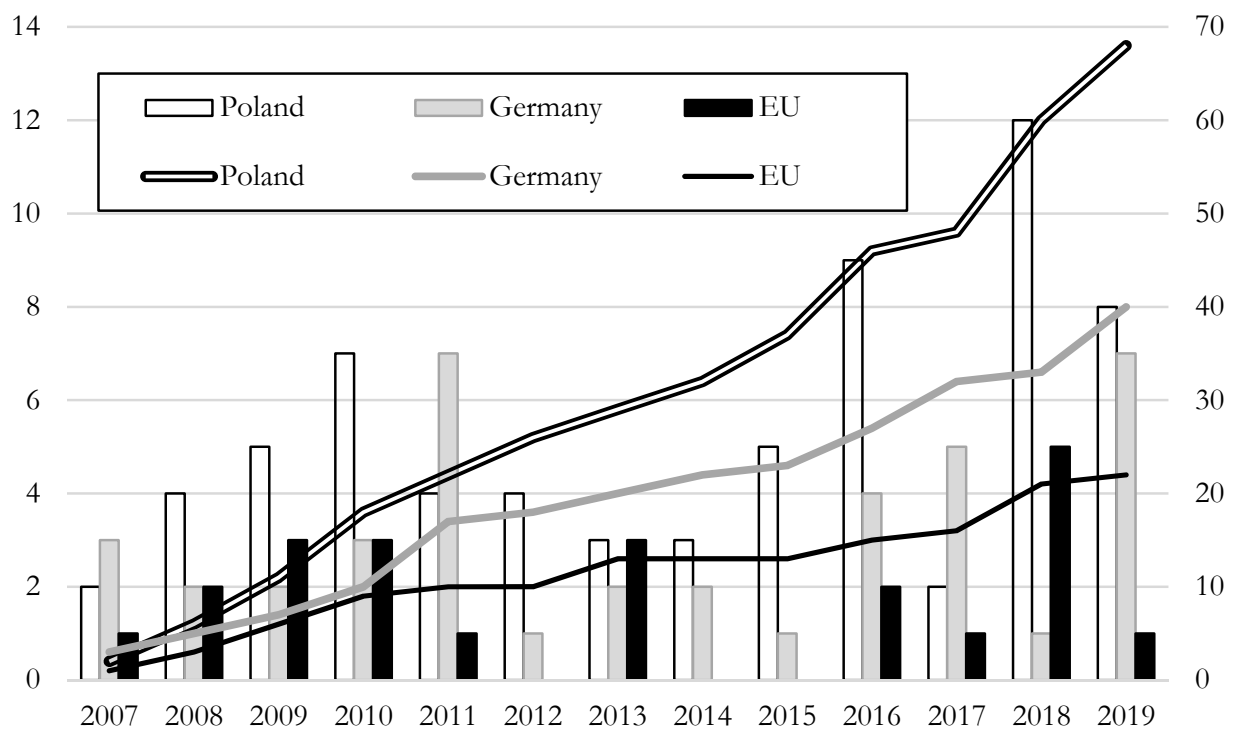

Explanations: The bars represent the number of laws in the respective year (left vertical axis) and the lines show the aggregated number (right vertical axis).

Source: author's own elaboration based on: [www 1; www 2; Act 11 March, 2004]. 
An isolated comparison of the number of changes in the respective year (illustrated by bars in chart 1) is not conclusive enough. A change in the VAT Directive does not necessarily result in the adoption into the national law in the same year. In addition, other EU directives and the leeway provided by optional regulations must be taken into account. In some years, this may lead to differences between the number of VAT Directive amendments and national legislative initiatives (see for example chart 1, 2018 versus 2019). Similar deviations can be observed between Germany and Poland (see for example chart 1, 2010 versus 2011).

In this context, it is more appropriate to consider the whole period. As expected, the aggregated number of VAT Directive amendments is lower than the number of changes to the German and Polish VAT Acts (displayed by lines in chart 1). However, the increasing deviation between the number of amendments for Germany and Poland is noticeable and suggests a higher VAT complexity in Poland. This observation should initially be considered merely as an indication, since the comparison ignores the extent of the respective law amendments as well as other aspects such as regulations, instructions from the tax authorities and the case law.

\section{VAT Complexity in Germany and Poland}

The First Directive has already addressed the simplicity and neutrality of the European VAT system [Council of the European ..., 1967a]. Tax neutrality implies that the legislator focuses on the fiscal function of the tax. However, VAT is not free from interventions of a redistributive or incentive nature. The reduced tax rate on food is primarily intended to relieve the burden on low-income households, and the recently introduced reduced tax rate on rail travel in Germany aims to make it more attractive compared to car use. The often unclear differentiation between transactions subject to the standard tax rate and the reduced tax rate does not stand for a simple VAT system.

However, the reduced tax rate is not the only complexity of the VAT law. Crossborder transactions as well as digital business models lead to special regulations such as the treatment of chain transactions, the reverse charge mechanism or special regulations on the place of supply of services. This is in line with the findings of some studies that identify higher compliance costs for cross-border activities [Verwaal, Cnossen, 2002; European Tax Survey, 2004].

In the study on compliance with tax obligations [Paying Taxes, 2020b], the international ranking takes into account, among other indicators, the time needed to comply with consumption taxes, VAT refund and the time to obtain this refund (see table 1). These measures can be interpreted as a proxy for compliance costs and thus for the complexity of the VAT system. All three relevant indicators speak for a higher complexity in Poland compared to Germany. A significant difference can be seen in the time needed to comply with consumption tax (172 hours in Poland versus 43 hours in Germany per year, see table 1). The time required in Poland is the longest among OECD countries, which ranks Poland last in this group with re- 
gard to the complexity of consumption tax [Tax Foundation, 2019]. By comparison, the time required in Estonia is only 14 hours. This is one of the reasons, why Tax Foundation [Bunn, Asen, 2019] considers tax system of this country as the most competitive one among the OECD members.

The reasons for the immense time needed to comply with VAT in Poland are connected with measures taken to combat tax fraud. While 43 hours have been needed in Germany with no change since 2004, Poland has experienced great volatility. From 116 hours in each of the years 2004 to 2007, the number of hours increased to the record level of 183 in 2008 and then gradually decreased to 96 hours in 2016 [Paying Taxes, 2020a]. The near doubling of this time to 172 hours since 2017 is clearly a result of the introduction of SAF-T (Standard Audit File for Tax). Since 2017, the obligation to submit this file for VAT purposes applies to small and medium-sized companies. This corresponds to the study by PwC and the World Bank Group [2020b], which measures the indicators for a medium-size company. It remains to be seen whether the high implementation costs will be (over-)compensated by savings due to process automation.

TABLE 1

Paying Taxes indicators for 2018

\begin{tabular}{|l|c|c|c|}
\hline \multicolumn{1}{|c|}{ Selected items and countries } & Estonia & Germany & Poland \\
\hline Ease of paying taxes score & 89.9 & 82.2 & 76.4 \\
\hline Hours to comply (per year) & 50 & 218 & 334 \\
\hline CIT & 5 & 41 & 59 \\
\hline Labour tax & 31 & 134 & 103 \\
\hline Consumption tax & 14 & 43 & 172 \\
\hline Number of payments & 8 & 9 & 7 \\
\hline Post-filing index & 99.4 & 97.7 & 77.4 \\
\hline Hours to comply with a VAT refund & 1.3 & 0 & 8 \\
\hline Weeks to obtain a VAT refund & 2.3 & 5.2 & 8.2 \\
\hline Rank (out of 189) & 12 & 46 & 77 \\
\hline The World Bank (2020) provides explanations on data and methodology. \\
\hline
\end{tabular}

Source: author's own elaboration based on: [Paying Taxes, 2020b; Paying Taxes..., 2020].

In addition to the compliance costs discussed above, I compare the German and Polish VAT laws as well as a selected amendment to these laws to gain further insights into the VAT complexity in these countries.

The higher VAT complexity in Poland is also reflected by the Polish VAT Act, which is much more extensive in terms of the number of regulations and the number of words and characters than its German counterpart (table 2). More than twice as many words and signs in the Polish law (table 2, column 3) could have a purely linguistic reason. The VAT Directive in the national language versions of the EU Member States (table 2, columns 4 and 5) is an appropriate tool to verify this. 
It turns out that the Polish language needs roughly the same number of words and characters as German to formulate the VAT legal framework (table 2, column 6).

TABLE 2

VAT Directive and VAT Act in Germany and Poland

\begin{tabular}{|c|c|c|c|c|c|c|}
\hline & \multicolumn{3}{|c|}{ VAT Act } & \multicolumn{3}{|c|}{ VAT Directive } \\
\hline & GER & PL & PL/GER & GER & PL & PL/GER \\
\hline Column & 1 & 2 & 3 & 4 & 5 & 6 \\
\hline Last provision & $\int 29$ & Art. 176 & & \multicolumn{3}{|c|}{ Article 414} \\
\hline Number of annexes & 4 & 7 & & \multicolumn{3}{|c|}{12} \\
\hline Words* & 37.3 & 89.0 & $239 \%$ & 52.7 & 52.2 & $99 \%$ \\
\hline Characters (no spaces)* & 227.3 & 531.5 & $234 \%$ & 329.3 & 302.7 & $92 \%$ \\
\hline Characters per word & 6.10 & 5.97 & & 6.25 & 5.79 & \\
\hline Characters (with spaces)* & 264.0 & 620.9 & $235 \%$ & 384.5 & 357.5 & $93 \%$ \\
\hline
\end{tabular}

Source: author's own elaboration based on: [Act of 11 March, 2004; Act of 21 February, 2005; Council of the European Union, 2006].

The higher VAT complexity in Poland, measured by the volume of the legal text, may result, on one hand, from a linguistically and structurally complicated form of implementation of the VAT Directive and, on the other hand, from special regulations. Since these special tax provisions are, for instance, in place to combat tax fraud, VAT complexity can be justified.

In order to isolate the effects of the special regulations, I study a specific amendment to the VAT Directive, which both Germany and Poland have implemented. Both language versions of the Vouchers Directive [Council of the European Union, 2016], as the chosen amendment, show a similar pattern to that found under the VAT Directive. The German version contains more words, which are on average longer and, therefore, require more characters (see: table 3, columns 1-3; table 2, columns 4-6). However, an adoption of the amendment with the same content in both countries shows that the extent of the Polish implementation is almost twice as high as in Germany (table 3, columns 4-6).

A comparison of the implementations of the Vouchers Directive with the VAT Acts reveals that the higher VAT complexity in Poland can be explained largely by a complicated language and structure used by the legislator (see: table 3, column 6; table 2, column 3). To deepen this analysis, I compare the proxies for the number of paragraph references in both languages as well as the repetitions of one of the core terms "taxable person(s)" in the VAT Act and in the implementation of the Vouchers Directive (table 4). 
TABLE 3

EU Vouchers Directive and its implementation in Germany and Poland

\begin{tabular}{|l|ccc|ccc|}
\cline { 2 - 7 } \multicolumn{1}{c|}{} & \multicolumn{3}{c|}{ EU Vouchers Directive } & \multicolumn{3}{c|}{ Implementation } \\
& GER & PL & PL/GER & GER & PL & PL/GER \\
\hline Column & 1 & 2 & 3 & 4 & 5 & 6 \\
Words & 443 & 390 & $88 \%$ & 376 & 746 & $198 \%$ \\
Characters (no spaces) & 3,108 & 2,518 & $81 \%$ & 2,394 & 4,475 & $187 \%$ \\
Characters per word & 7.02 & 6.46 & & 6.37 & 6.00 & \\
Characters (with spaces) & 3,546 & 2,908 & $82 \%$ & 2,763 & 5,204 & $188 \%$ \\
\hline
\end{tabular}

Source: author's own elaboration based on Annex (table A1 and A2).

The significantly higher number of paragraph references and repetitions reveals the weakness of the Polish VAT Act. In the case of the complete legal acts, the outcome also includes the numbering of regulations and paragraphs (table 4, columns 1-3), which can distort the results. For this reason, I present manually determined numbers for the amendment laws strictly for paragraph references (table 4, columns 4-6). Once again, it is apparent that the Polish legislator more often refers to other regulations. They also more frequently repeat the term "taxable person". Both indicate the use of a more complex language by the Polish legislator compared to their German counterpart.

TABLE 4

VAT Act and Implementation of the EU Vouchers Directive

\begin{tabular}{|c|c|c|c|c|c|c|}
\hline \multirow{2}{*}{$\begin{array}{l}\text { Number of hits when searching } \\
\text { for: "GER"/“PL" (...) }\end{array}$} & \multicolumn{3}{|c|}{ VAT Act } & \multicolumn{3}{|c|}{ Implementation ${ }^{a}$} \\
\hline & GER & PL & PL/GER & GER & PL & PL/GER \\
\hline Column & 1 & 2 & 3 & 4 & 5 & 6 \\
\hline "s"/“art." & 781 & 1,343 & $172 \%$ & 2 & 8 & $400 \%$ \\
\hline $\begin{array}{l}\text { “Abs.", “Absatz”, } \\
\text { “Absätze"/“ust.”b }\end{array}$ & 683 & 1,691 & $248 \%$ & 4 & 8 & $200 \%$ \\
\hline "Nr."/“pkt" & 172 & 537 & $312 \%$ & - & - & \\
\hline "Unternehmer"/"podatnik_" c & 451 & 1,050 & $233 \%$ & 8 & 13 & $163 \%$ \\
\hline \multicolumn{7}{|c|}{$\begin{array}{l}\text { a excluding the numbering and headings of the regulations } \\
\text { b paragraph(s) } \\
\text { c taxable person(s) }\end{array}$} \\
\hline
\end{tabular}

Source: author's own elaboration based on: Annex (table A2).

\section{Conclusions}

Tax complexity is generally viewed in a negative way. However, it should be noted that it results in part from the realization of important tasks such as income redistribution or the elimination of international tax planning. VAT is considered to 
be an efficient, neutral and revenue-generating tax. As such it is predestined for a simple design. Simplicity can be increased by standardising the VAT law, as it is happening in the EU.

The VAT complexity in Poland significantly exceeds the complexity of the German VAT system, although both systems are based on the VAT Directive. This is true for all analysed aspects. In Poland the compliance costs of VAT are significantly higher than in Germany. However, the time for VAT compliance in Germany is considerably higher than in the exemplary Estonia. The Polish VAT law is amended more frequently and is much more comprehensive than its German counterpart. This can be only partially justified by special regulations to combat the tax fraud. The high VAT complexity in Poland is also due to the complicated language and structure of the law.

\section{References}

Act of 11 December 2018, Gesetz zur Vermeidung von Umsatzsteuerausfällen beim Handel mit Waren im Internet und zur Änderung weiterer steuerlicher Vorschriften, Bundesgesetzblatt 2018, Teil I, Nr 45, 2338.

Act of 11 March 2004, Ustawa o podatku od towarów i usług, Akty zmieniające, http://prawo.sejm.gov.pl/isap.nsf/DocDetails.xsp?id=WDU20040540535 [date of entry: 03.03.2020].

Act of 21 February 2005, Umsatzsteuergesetz, Bundesgesetzblatt 2005, Teil I, No. 13,386 , as amended.

Act of 22 November 2018, Ustawa o zmianie ustawy o podatku od towarów i usług, Dz. U. 2018, Item 2433.

Bunn D., Asen E., 2019, International Tax Competitiveness Index 2019, Tax Foundation, Washingtion, https://files.taxfoundation.org/20190930115625/2019-InternationalTax-Competitiveness-Index.pdf [date of entry: 05.03.2020].

Council of the European Economic Community, 1967a, First Council Directive of 11 April 1967 on the harmonisation of legislation of Member States concerning turnover taxes (67/227/EEC), Official Journal of the European Communities, $1301 / 67$.

Council of the European Economic Community, 1967b, Second Council Directive of 11 April 1967 on the harmonisation of legislation of Member States concerning turnover taxes Structure and procedures for application of the common system of value added tax (67/228/EEC), Official Journal of the European Communities, 1303/67.

Council of the European Economic Community, 1977, Sixth Council Directive of 17 May 1977 on the harmonization of the laws of the Member States relating to turnover taxes - Common system of value added tax: uniform basis of assessment (77/388/EEC), Official Journal of the European Communities, L145/1. 
Council of the European Union, 2006, Council Directive 2006/112/EC of 28 November 2006 on the common system of value added tax, Official Journal of the European Union, L347/1.

Council of the European Union, 2016, Council Directive (EU) 2016/1065 of 27 June 2016 amending Directive 2006/112/EC as regards the treatment of vouchers, Official Journal of the European Union, L177/9.

Eichfelder S., Vaillancourt F., 2014, Tax compliance costs: A review of cost burdens and cost structures, arqus Discussion Paper, no. 178, pp. 1-42.

European Tax Survey, 2004, European Commission, Working Paper, no. 3.

Existing EU legal framework, 2020, European Commission, https://ec.europa.eu/ taxation_customs/business/vat/existing-eu-legal-framework_en [date of entry: 04.03.2020].

Hoppe T., Schanz D., Sturm S., Sureth-Sloane C., 2019, Measuring Tax Complexity Across Countries: A Survey Study on MNCs, Accounting for Transparency, Working Paper Series, no. 5, https://papers.ssrn.com/sol3/papers.cfm?abstract_id=3469 663.

James S., Sawyer A., Wallschutzky I., 2015, Tax simplification: A review of initiatives in Australia, New Zealand and the United Kingdom, "eJournal of Tax Research", vol. 13, no.1, pp. 280-302.

Klenk F., 2019, Wesen der Umsatzsteuer, Verhältnis von nationalem Recht zum Unionsrecht, Sölch/Ringleb Umsatzsteuergesetz Kommentar, Rn. 1-36.

Krótka historia VAT w Polsce, 2019, Polski Instytut Ekonomiczny, „Policy Paper”, nr 3, pp. 1-34, http://pie.net.pl/wp-content/uploads/2019/03/PIE-Historia-VAT. pdf [date of entry: 04.03.2020].

Lindner C., 2020, Sieben Maßnahmen für eine beherzte Wirtschaftspolitik gegen die CoronaKrise, "Handelsblatt", https://www.handelsblatt.com/meinung/gastbeitraege/ gastkommentar-sieben-massnahmen-fuer-eine-beherzte-wirtschaftspolitik-gegendie-corona-krise/25590196.html [date of entry: 02.03.2020].

OTS, 2020, https://www.gov.uk/government/organisations/office-of-tax-simplification/about [date of entry: 10.12.2019].

OTS complexity index methodology June 2015, 2015, Office of Tax Simplification, https: //assets.publishing.service.gov.uk/government/uploads/system/uploads/attachment_data/file/438587/OTS_complexity_index_methodology_June_2015. pdf [date of entry: 03.03.2020].

Paying Taxes 2020, 2020a, PWC, https://www.pwc.com/gx/en/services/tax/publications/paying-taxes-2020/explorer-tool.html [date of entry: 05.03.2020].

Paying Taxes 2020, 2020b, PwC, World Bank Group, https:/ /www.pwc.com/gx/en/ services/tax/publications/paying-taxes-2020/overall-ranking-and-data-tables.html [date of entry: 03.03.2020].

Paying Taxes methodology, 2020, The World Bank, https://www.doingbusiness.org/ en/methodology/paying-taxes [date of entry: 03.03.2020].

Pedersen H., Moerup C., Andersen C., Findsen L., Nielsen J., Lang T., 2013, A review and Evaluation of Methodologies to calculate tax compliance costs, European Commission, Working Paper, no. 40. 
Schäfers M., 2010, Union und FDP in der Steuerklemme, "Frankfurter Allgemeine", https://www.faz.net/aktuell/wirtschaft/wirtschaftspolitik/der-schwere-wegzu-steuervereinfachung-union-und-fdp-in-der-steuerklemme-15556.html [date of entry: 02.03.2020].

Slemrod J., 1984, Optimal Tax Simplification: Toward a Framework for Analysis, Proceedings of the $76^{\text {th }}$ Annual Conference of the National Tax Association, vol. 76, pp. 158-162.

Slemrod J., 2005, The Etiology of Tax Complexity: Evidence from U.S. State Income Tax Systems, "Public Finance Review”, vol. 33(3), pp. 279-299.

Verwaal E., Cnossen S., 2002, Europe's New Border Taxes, “Journal of Common Market Studies”, vol. 40(2), pp. 309-330, DOI: 10.1111/1468-5965.00356.

Warskett G., Winer S., Hettich W., 1998, The Complexity of Tax Structure in Competitive Political Systems, "International Tax and Public Finance”, vol. 5, pp. 123-151.

www 1, https://beck-online.beck.de/Dokument?vpath=bibdata $\% 2$ Fges $\% 2$ Fustg $\% 2$ Fcont $\% 2$ Fustg.aendverz.htm\&anchor $=Y-100-G-U S T G-N A M E-A E N D V E R Z$ [date of entry: 03.03.2020].

www 2, https://beck-online.beck.de/Dokument?vpath=bibdata $\% 2 F g e s \% 2 F e w g \_r l$

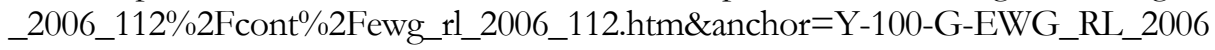
_112-NAME-AENDVERZ [date of entry: 03.03.2020].

\section{ANNEX}

TABLE A1

\section{EU Vouchers Directive}

\begin{tabular}{|c|c|c|}
\hline $\begin{array}{l}\text { Words: } 468^{*} \\
\text { Characters (no spaces): } 2,323^{*} \text { [per } \\
\text { word: } 4.96^{*} \text { ] } \\
\text { Characters (with spaces): } 2,778^{*} \\
\text { * grey lines are not included }\end{array}$ & $\begin{array}{l}\text { Words: } 390^{*} \\
\text { Characters (no spaces): } 2,518^{*} \\
\text { [per word: } 6.46^{*} \text { ] } \\
\text { Characters (with spaces): } 2,908^{*}\end{array}$ & $\begin{array}{l}\text { Words: } 443^{*} \\
\text { Characters (no spaces): } 3,108^{*} \\
\text { [per word: } 7.02^{*} \text { ] } \\
\text { Characters (with spaces): } 3,546^{*}\end{array}$ \\
\hline $\begin{array}{l}\text { EU Vouchers Directive [Council } \\
\text { of the European Union 2016] }\end{array}$ & $\begin{array}{l}\text { The } P \\
\text { of th }\end{array}$ & $\begin{array}{c}\text { The German version } \\
\text { of the Directive }\end{array}$ \\
\hline $\begin{array}{l}\text { Article 30a } \\
\text { For the purposes of this Directive, } \\
\text { the following definitions shall apply: } \\
\text { (1) 'voucher' means an instrument } \\
\text { where there is an obligation to ac- } \\
\text { cept it as consideration or part con- } \\
\text { sideration for a supply of goods or } \\
\text { services and where the goods or } \\
\text { services to be supplied or the iden- } \\
\text { tities of their potential suppliers are } \\
\text { either indicated on the instrument } \\
\text { itself or in related documentation, } \\
\text { including the terms and conditions } \\
\text { of use of such instrument; } \\
\text { (2) 'single-purpose voucher' means } \\
\text { a voucher where the place of supply } \\
\text { of the goods or services to which } \\
\text { the voucher relates, and the VAT } \\
\text { due on those goods or services, are }\end{array}$ & $\begin{array}{l}\text { Artykuł 30a } \\
\text { Do celów niniejszej dyrektywy za- } \\
\text { stosowanie mają następujące defini- } \\
\text { cje: } \\
\text { 1) »bon na towary lub usługi (bon)« } \\
\text { oznacza instrument, z którym wiąże } \\
\text { się obowiązek jego przyjęcia jako } \\
\text { wynagrodzenia lub części wynagro- } \\
\text { dzenia za dostawę towarów lub } \\
\text { świadczenie usług i w przypadku } \\
\text { którego towary lub usługi, które } \\
\text { mają zostać dostarczone lub wyko- } \\
\text { nane, lub tożsamość potencjalnych } \\
\text { dostawców lub usługodawców sa } \\
\text { wskazane w samym instrumencie lub } \\
\text { określone w powiązanej dokumenta- } \\
\text { cji, w tym w warunkach wykorzysta- } \\
\text { nia takiego instrumentu; } \\
\text { 2) »bon jednego przeznaczenia» }\end{array}$ & $\begin{array}{l}\text { Artikel 30a } \\
\text { Für die Zwecke dieser Richtlinie } \\
\text { gelten folgende Begriffsbestimmun- } \\
\text { gen: } \\
\text { 1. „Gutschein“ ist ein Instrument, } \\
\text { bei dem die Verpflichtung besteht, es } \\
\text { als Gegenleistung oder Teil einer sol- } \\
\text { chen für eine Lieferung von Gegen- } \\
\text { ständen oder eine Erbringung von } \\
\text { Dienstleistungen anzunehmen und } \\
\text { bei dem die zu liefernden Gegen- } \\
\text { stände oder zu erbringenden } \\
\text { Dienstleistungen oder die Identität } \\
\text { der möglichen Lieferer oder } \\
\text { Dienstleistungserbringer entweder } \\
\text { auf dem Instrument selbst oder in } \\
\text { damit zusammenhängenden Unterla- } \\
\text { gen, einschließlich der Bedingungen } \\
\text { für die Nutzung dieses Instruments, }\end{array}$ \\
\hline
\end{tabular}


known at the time of issue of the voucher;

(3) 'multi-purpose voucher' means a voucher, other than a single-purpose voucher.

\section{Article 30b}

1. Each transfer of a single-purpose voucher made by a taxable person acting in his own name shall be regarded as a supply of the goods or services to which the voucher relates. The actual handing over of the goods or the actual provision of the services in return for a singlepurpose voucher accepted as consideration or part consideration by the supplier shall not be regarded as an independent transaction.

Where a transfer of a single-purpose voucher is made by a taxable person acting in the name of another taxable person, that transfer shall be regarded as a supply of the goods or services to which the voucher relates made by the other taxable person in whose name the taxable person is acting.

Where the supplier of goods or services is not the taxable person who, acting in his own name, issued the single-purpose voucher, that supplier shall however be deemed to have made the supply of the goods or services related to that voucher to that taxable person.

2. The actual handing over of the goods or the actual provision of the services in return for a multi-purpose voucher accepted as consideration or part consideration by the supplier shall be subject to VAT pursuant to Article 2, whereas each preceding transfer of that multipurpose voucher shall not be subject to VAT.

Where a transfer of a multi-purpose voucher is made by a taxable person other than the taxable person carrying out the transaction subject to VAT pursuant to the first subparagraph, any supply of services that can be identified, such as distribution or promotion services, shall be

oznacza bon, w przypadku którego miejsce dostawy towarów lub świadczenia usług, których dany bon dotyczy, oraz VAT należny z tytułu tych towarów lub usług są znane w chwili emisji bonu;

3) »bon różnego przeznaczenia« oznacza bon inny niż bon jednego przeznaczenia.

\section{Artykuł 30b}

1. Każdy transfer bonu jednego przeznaczenia dokonany przez podatnika działającego we własnym imieniu uznaje się za dostawę towarów lub świadczenie usług, których bon dotyczy. Faktycznego przekazania towarów lub faktycznego świadczenia usług w zamian za bon jednego przeznaczenia przyjmowany przez dostawcę lub usługodawcę jako wynagrodzenie lub część wynagrodzenia nie uznaje się za niezależną transakcję. Gdy transferu bonu jednego przeznaczenia dokonuje podatnik działający w imieniu innego podatnika, taki transfer uznaje się za dostawę towarów lub świadczenie usług, których bon dotyczy, dokonane przez tego drugiego podatnika, w którego imieniu działa pierwszy podatnik. W przypadku gdy dostawca towarów lub usługodawca nie jest podatnikiem, który - działając we własnym imieniu - wyemitowal dany bon jednego przeznaczenia, uznaje się jednak, że dany dostawca lub usługodawca dokonał dostawy towarów lub świadczenia usług, których ten bon dotyczy, na rzecz tego podatnika.

2. Faktyczne przekazanie towarów lub faktyczne świadczenie usług dokonane w zamian za bon różnego przeznaczenia przyjmowany przez dostawcę lub usługodawcę jako wynagrodzenie lub część wynagrodzenia podlega opodatkowaniu podatkiem VAT zgodnie $z$ art. 2, natomiast każdy poprzedzający transfer tego bonu różnego przeznaczenia nie podlega opodatkowaniu VAT. W przypadku gdy transferu bonu różnego przeznaczenia dokonuje podatnik inny niż podatnik dokonujący transakcji podlegającej opodatkowaniu VAT zgodnie $\mathrm{z}$ akapitem pierwszym, każde świadczenie usług, które angegeben sind;

2. „Einzweck-Gutschein“ist ein Gutschein, bei dem der Ort der Lieferung der Gegenstände oder der Erbringung der Dienstleistungen, auf die sich der Gutschein bezieht, und die für diese Gegenstände oder Dienstleistungen geschuldete Mehrwertsteuer zum Zeitpunkt der Ausstellung des Gutscheins feststehen;

3. „Mehrzweck-Gutschein“ist ein Gutschein, bei dem es sich nicht um einen Einzweck-Gutschein handelt.

Artikel 30b
(1) Jede Übertragung eines Einzweck-Gutscheins durch einen Steuerpflichtigen, der im eigenen Namen handelt, gilt als eine Lieferung der Gegenstände oder Erbringung der Dienstleistungen, auf die sich der Gutschein bezieht. Die tatsächliche Übergabe der Gegenstände oder die tatsächliche Erbringung der Dienstleistungen, für die ein EinzweckGutschein als Gegenleistung oder Teil einer solchen von dem Lieferer oder Dienstleistungserbringer angenommen wird, gilt nicht als unabhängiger Umsatz. Erfolgt eine Übertragung eines Einzweck-Gutscheins durch einen Steuerpflichtigen, der im Namen eines anderen Steuerpflichtigen handelt, gilt diese Übertragung als eine Lieferung der Gegenstände oder Erbringung der Dienstleistungen, auf die sich der Gutschein bezieht, durch den anderen Steuerpflichtigen, in dessen Namen der Steuerpflichtige handelt. Handelt es sich bei dem Lieferer von Gegenständen oder dem Erbringer von Dienstleistungen nicht um den Steuerpflichtigen, der, im eigenen Namen handelnd, den Einzweck-Gutschein ausgestellt hat, so wird dieser Lieferer von Gegenständen bzw. Erbringer von Dienstleistungen dennoch so behandelt, als habe er diesem Steuerpflichtigen die Gegenstände oder Dienstleistungen in Bezug auf diesen Gutschein geliefert oder erbracht.

(2) Die tatsächliche Übergabe der Gegenstände oder die tatsächliche Erbringung der Dienstleistungen, für die der Lieferer der Gegenstände oder Erbringer der Dienstleistungen einen Mehrzweck-Gutschein als Gegenleistung oder Teil einer solchen annimmt, unterliegt der Mehrwertsteuer gemäß Artikel 2, wohingegen jede vorangegangene Übertragung 


\begin{tabular}{|c|c|c|}
\hline subject to VAT. & $\begin{array}{l}\text { można wskazać, takie jak usługi } \\
\text { dystrybucji lub promocji, podlega } \\
\text { opodatkowaniu VAT. }\end{array}$ & $\begin{array}{l}\text { dieses Mehrzweck-Gutscheins nicht } \\
\text { der Mehrwertsteuer unterliegt. Wird } \\
\text { ein Mehrzweck-Gutschein von } \\
\text { einem anderen Steuerpflichtigen als } \\
\text { dem Steuerpflichtigen, der den ge- } \\
\text { mäß Unterabsatz } 1 \text { der Mehrwert- } \\
\text { steuer unterliegenden Umsatz er- } \\
\text { bringt, übertragen, so unterliegen alle } \\
\text { bestimmbaren Dienstleistungen wie } \\
\text { etwa Vertriebs- oder Absatzförde- } \\
\text { rungsleistungen der Mehrwertsteuer. }\end{array}$ \\
\hline $\begin{array}{l}\text { Article 73a } \\
\text { Without prejudice to Article 73, the } \\
\text { taxable amount of the supply of } \\
\text { goods or services provided in re- } \\
\text { spect of a multi-purpose voucher } \\
\text { shall be equal to the consideration } \\
\text { paid for the voucher or, in the ab- } \\
\text { sence of information on that con- } \\
\text { sideration, the monetary value indi- } \\
\text { cated on the multi-purpose voucher } \\
\text { itself or in the related documenta- } \\
\text { tion, less the amount of VAT re- } \\
\text { lating to the goods or services sup- } \\
\text { plied. }\end{array}$ & \begin{tabular}{|c|}
\multicolumn{2}{|c|}{ Artykuł 73a } \\
Bez uszczerbku dla art. 73 podstawa \\
opodatkowania dostawy towarów \\
lub świadczenia usług w odniesieniu \\
do bonu różnego przeznaczenia jest \\
równa wynagrodzeniu zapłaconemu \\
za taki bon lub - gdy informacje \\
dotyczące tego wynagrodzenia sa \\
niedostępne - wartości pieniężnej \\
wskazanej na samym bonie różnego \\
przeznaczenia lub w powiązanej do- \\
kumentacji, pomniejszonej o kwotę \\
VAT zwiazzana z dostarczonymi to- \\
warami lub świadczonymi usługami.
\end{tabular} & \begin{tabular}{l}
\multicolumn{3}{|c|}{ Artikel 73a } \\
Bei der Lieferung von Gegenständen \\
oder bei der Erbringung von \\
Dienstleistungen, die in Bezug auf \\
einen Mehrzweck-Gutschein erfolgt, \\
entspricht die Steuerbemessungs- \\
grundlage unbeschadet des Artikels \\
73 der für den Gutschein gezahlten \\
Gegenleistung oder, in Ermangelung \\
von Informationen über diese Ge- \\
genleistung, dem auf dem Mehr- \\
zweck-Gutschein selbst oder in den \\
damit zusammenhängenden Unterla- \\
gen angegebenen Geldwert, abzüg- \\
lich des Betrags der auf die geliefer- \\
ten Gegenstände oder die erbrachten \\
Dienstleistungen erhobenen Mehr- \\
wertsteuer.
\end{tabular} \\
\hline
\end{tabular}

Source: Autor's own elaboration based on: [Council of the European Union, 2016].

TABLE A2

\section{Amendments to the Polish and German VAT Act according to the EU Vouchers Directive}

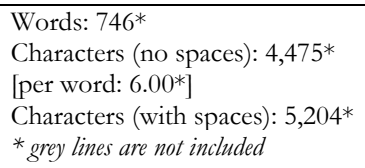

\section{Polish VAT \\ Act of 11th March 2004}

\section{Art. 2 Ilekeró $w$ dalsyych przepisach jest mowa o:}

41) bonie - rozumie się przez to instrument, z którym wiąże się obowiązek jego przyjęcia jako wynagrodzenia lub części wynagrodzenia za dostawę towarów lub świadczenie usług, w przypadku którego towary, które mają zostać dostarczone, lub usługi, które mają zostać wykonane, lub tożsamość potencjalnych dostawców lub usługodawców są wskazane w samym instrumencie lub określone w powiązanej dokumentacji, w tym w warunkach wykorzystania tego instrumentu;

42) emisji bonu - rozumie się przez to pierwsze wprowadzenie bonu do obrotu;

43) bonie jednego przeznaczenia - rozumie się przez to bon, w przypadku którego miejsce dostawy towarów lub świadczenia usług, których bon dotyczy, oraz kwota należnego podatku, podatku od wartości dodanej lub
$376^{*}$

$2,394^{*}$

[per word: $6.37^{*}$ ]

$2,763^{*}$

\section{German VAT \\ Act of 21st February 2005}

\section{\ 3 Lieferung, sonstige Leistung} ...

(13) Ein Gutschein (Einzweckoder Mehrzweck-Gutschein) ist ein Instrument, bei dem

1. die Verpflichtung besteht, es als vollständige oder teilweise Gegenleistung für eine Lieferung oder sonstige Leistung anzunehmen und

2. der Liefergegenstand oder die sonstige Leistung oder die Identität des leistenden Unternehmers entweder auf dem Instrument 
podatku o podobnym charakterze $\mathrm{z}$ tytułu dostawy tych towarów lub świadczenia tych usług są znane w chwili emisji tego bonu;

44) bonie różnego przeznaczenia - rozumie się przez to bon inny niż bon jednego przeznaczenia;

45) transferze bonu - rozumie się przez to emisję bonu oraz każde przekazanie tego bonu po jego emisji.

\section{Rozdział 2a}

Opodatkowanie w przypadku stosowania bonów

Art. 8a. 1. Transfer bonu jednego przeznaczenia dokonany przez podatnika działającego we własnym imieniu uznaje się za dostawę towarów lub świadczenie usług, których ten bon dotyczy.

2. Faktycznego przekazania towarów lub faktycznego świadczenia usług w zamian za bon jednego przeznaczenia przyjmowany przez dostawcę lub usługodawcę jako wynagrodzenie lub część wynagrodzenia nie uznaje się za niezależną transakcję w części, w której wynagrodzenie stanowił bon.

3. Jeżeli transferu bonu jednego przeznaczenia dokonuje podatnik działający w imieniu innego podatnika, uznaje się, że taki transfer stanowi dostawę towarów lub świadczenie usług, których ten bon dotyczy, dokonane przez podatnika, w imieniu którego działa podatnik.

4. W przypadku, gdy dostawca towarów lub usługodawca nie jest podatnikiem, który działając we własnym imieniu, wyemitował bon jednego przeznaczenia, uznaje się, że ten dostawca lub usługodawca dokonał odpowiednio dostawy towarów lub świadczenia usług, których ten bon dotyczy, na rzecz podatnika, który wyemitował ten bon.

Art. 8b. 1. Faktyczne przekazanie towarów lub faktyczne świadczenie usług dokonane $\mathrm{w}$ zamian za bon różnego przeznaczenia przyjmowany przez dostawcę lub usługodawcę jako wynagrodzenie lub część wynagrodzenia podlega opodatkowaniu podatkiem. Nie podlega opodatkowaniu podatkiem wcześniejszy transfer bonu różnego przeznaczenia.

2. W przypadku, gdy transferu bonu różnego przeznaczenia dokonuje podatnik inny niż podatnik dokonujący czynności podlegającej opodatkowaniu podatkiem zgodnie $z$ ust. 1, opodatkowaniu podatkiem podlegają usługi pośrednictwa oraz inne usługi, które można zidentyfikować, takie jak usługi dystrybucji lub promocji, dotyczące tego bonu.

Art. 17. 1. Podatnikami są również...

4) nabywające usługi, jeżeli...

b) usługobiorcą jest:

- w przypadku transferu bonów jednego przeznaczenia, w przypadku których miejscem świadczenia usług, których te bony dotyczą, jest terytorium kraju - podatnik, o którym mowa w art. 15 , lub osoba prawna niebędąca podatnikiem, o którym mowa w art. 15 ,

5) nabywające towary...

a) dokonującym ich dostawy...

- innej niż transfer bonów jednego przeznaczenia

b) nabywcą jest:

- w przypadku transferu bonów jednego przeznaczenia, w przypadku których miejscem dostawy towarów, których te bony dotyczą, jest terytorium kraju - podatnik, o którym mowa w art. 15, lub osoba prawna niebędąca podatnikiem, o którym mowa w art. 15 ,

\section{Art. 19a. 1. Obowiązek podatkowy:}

1a. W przypadku, o którym mowa w art. 8a ust. 1 i 3, obowiązek podatkowy powstaje $z$ chwilą dokonania transferu bonu jednego przeznaczenia. 4a. W przypadku, o którym mowa w art. 8a ust. 1 i 3, dostawę towarów uznaje się za dokonana, a usługę uznaje się za wykonaną z chwilą dokonania transferu bonu jednego przeznaczenia.

Art. 21. 1. Mały podatnik:

6. Przepis ust. 1:

2) nie ma zastosowania do:

a) dostawy towarów i świadczenia usług, o których mowa w art. 8a ust. 1 i 3 ,

selbst oder in damit zusammenhängenden Unterlagen, einschließlich der Bedingungen für die Nutzung dieses Instruments, angegeben sind.

Instrumente, die lediglich zu einem Preisnachlass berechtigen, sind keine Gutscheine im Sinne des Satzes 1.

(14) Ein Gutschein im Sinne des Absatzes 13, bei dem der Ort der Lieferung oder der sonstigen Leistung, auf die sich der Gutschein bezieht, und die für diese Umsätze geschuldete Steuer zum Zeitpunkt der Ausstellung des Gutscheins feststehen, ist ein Einzweck-Gutschein. Überträgt ein Unternehmer einen Einzweck-Gutschein im eigenen Namen, gilt die Übertragung des Gutscheins als die Lieferung des Gegenstands oder die Erbringung der sonstigen Leistung, auf die sich der Gutschein bezieht. Überträgt ein Unternehmer einen Einzweck-Gutschein im Namen eines anderen Unternehmers, gilt diese Übertragung als Lieferung des Gegenstands oder Erbringung der sonstigen Leistung, auf die sich der Gutschein bezieht, durch den Unternehmer, in dessen Namen die Übertragung des Gutscheins erfolgt. Wird die im Einzweck-Gutschein bezeichnete Leistung von einem anderen Unternehmer erbracht als dem, der den Gutschein im eigenen Namen ausgestellt hat, wird der leistende Unternehmer so behandelt, als habe er die im Gutschein bezeichnete Leistung an den Aussteller erbracht. Die tatsächliche Lieferung oder die tatsächliche Erbringung der sonstigen Leistung, für die ein Einzweck-Gutschein als Gegenleistung angenommen wird, gilt in den Fällen der Sätze 2 bis 4 nicht als unabhängiger Umsatz.

(15) Ein Gutschein im Sinne des Absatzes 13, bei dem es sich nicht um einen Einzweck-Gutschein handelt, ist ein Mehrzweck-Gutschein. Die tatsächliche Lieferung oder die tatsächliche Erbringung der sonstigen Leistung, für die der leistende Unternehmer einen Mehrzweck-Gutschein als vollständige oder teilweise Gegenleistung annimmt, unterliegt der 


\section{Podstawa opodatkowania}

$$
\text { Art. 29a. }
$$

1a. Podstawa opodatkowania z tytułu dostawy towarów lub świadczenia usług dokonanych w zamian za bon różnego przeznaczenia realizowany w całości, w odniesieniu do tego bonu, jest równa:

1) wynagrodzeniu zapłaconemu za ten bon różnego przeznaczenia, pomniejszonemu o kwotę podatku związaną z dostarczonymi towarami lub świadczonymi usługami;

2) wartości pieniężnej wskazanej na tym bonie różnego przeznaczenia lub w powiązanej dokumentacji, pomniejszonej o kwotę podatku związaną z dostarczonymi towarami lub świadczonymi usługami - w przypadku, gdy informacje dotyczące wynagrodzenia są niedostępne.

1b. Podstawa opodatkowania $z$ tytułu dostawy towarów lub świadczenia usług dokonanych w zamian za bon różnego przeznaczenia realizowany w części, w odniesieniu do tego bonu, jest równa odpowiedniej części:

1) wynagrodzenia zapłaconego za ten bon różnego przeznaczenia, pomniejszonej o kwotę podatku związaną z dostarczonymi towarami lub świadczonymi usługami;

2) wartości pieniężnej wskazanej na tym bonie różnego przeznaczenia lub w powiązanej dokumentacji, pomniejszonej o kwotę podatku związana z dostarczonymi towarami lub świadczonymi usługami - w przypadku, gdy informacje dotyczące wynagrodzenia są niedostępne.

1c. W przypadku, o którym mowa w ust. 1a i 1b, przepisy ust. 2 i 5 stosuje się odpowiednio.

Art. 106i. 1. Fakturę wystawia się:

9. Przepisów ust. 3, 4 i 8 nie stosuje się do wystawiania faktur w zakresie dostawy towarów lub świadczenia usług, o których mowa w art. 8a ust. 1 i 3 .

Source: author's own elaboration based on: [Act of 22 November, 2018; Act of 11 December, 2018].
Umsatzsteuer nach $\int 1$ Absatz 1 , wohingegen jede vorangegangene Übertragung dieses MehrzweckGutscheins nicht der Umsatzsteuer unterliegt.

Liegen bei der Entgegennahme eines Mehrzweck-Gutscheins ( 53 Absatz 15) keine Angaben über die Höhe der für den Gutschein erhaltenen Gegenleistung nach Satz 2 vor, so wird das Entgelt nach dem Gutscheinwert selbst oder nach dem in den damit zusammenhängenden Unterlagen angegebenen Geldwert bemessen, abzüglich der Umsatzsteuer, die danach auf die gelieferten Gegenstände oder die erbrachten Dienstleistungen entfällt.

\section{$\int 10$ Bemessungsgrundlage für Lieferungen, sonstige Leistun- gen und innergemeinschaft- liche Erwerbe}

